\title{
PENGARUH PEMBERIAN SERBUK BIJI LABU KUNING (Cucurbita moschata) TERHADAP PENURUNAN KOLESTEROL TOTAL TIKUS WISTAR HIPERKOLESTEROLEMIA
}

\author{
Feni Andari, Arintina Rahayuni*) \\ Program Studi Ilmu Gizi Fakultas Kedokteran Universitas Diponegoro \\ J1.Dr.Sutomo No.18, Semarang, Telp (024) 8453708, Email : gizifk@ undip.ac.id
}

\begin{abstract}
Background: Cardiovascular disease is the leading causes of death in the world. One of the cardiovascular risk factor is hypercholesterolemic, signed by elevated total cholesterol level in the blood. An appropriate management of total cholesterol level can reduce risks of cardiovascular disease. Pumpkin seed powder beneficial for lowering total cholesterol. This study aims to get the information on the effect of pumpkin seed on total cholesterol lowering in hypercholesterolemic Wistar rats.

Methods: This study was a true experimental with pre-post test randomized control group design with 24 rats which were induced hypercholesterolemic for 14 days, given pumpkin seed powder dosage P1: 0,54 g/rat/d; P2: 0,72 g/rat/d; P3: 0,90 g/rat/d for 14 days. Total cholesterol serum was measured by CHOD-PAP method before and after intervention. Data were analyzed by paired t-test and Annova.

Result: Total cholesterol lowering in the treatment 2 (P2) p=0,019 dan 3 (P3) p=0,026 after given pumpkin seed powder. The lowering continued in $P 2$ group from $71,8 \mathrm{mg} / \mathrm{dL}$ to $58,8 \mathrm{mg} / \mathrm{dL}$; P1 group from 66,5 $\mathrm{mg} / \mathrm{dL}$ to 54,7 $\mathrm{mg} / \mathrm{dL}$; and P3 group from $61,7 \mathrm{mg} / \mathrm{dL}$ to $53,7 \mathrm{mg} / \mathrm{dL}$. There was no effect of pumpkin seed powder on total cholesterol lowering between all groups $p=0,534$.

Conclusion: The administration of pumpkin seed powder in treatment group 2 (P2) dosages $0,72 \mathrm{~g} / \mathrm{rat} / \mathrm{d}$ and 3 (P3) dosages $0,90 \mathrm{~g} / \mathrm{rat} / \mathrm{d}$ for 14 days significant reduce the total cholesterol on rats hyperkolesterolemic.

Key words : pumpkin seed powder; total cholesterol; hypercholesterolemic
\end{abstract}

\begin{abstract}
ABSTRAK
Latar Belakang: Penyakit kardiovaskuler merupakan penyebab utama kematian di dunia. Salah satu faktor risikonya ialah hiperkolesterolemia yang ditandai oleh tingginya kolesterol total dalam darah. Pengendalian kolesterol total yang tepat dapat mengurangi risiko penyakit kardiovaskuler. Serbuk biji labu kuning bermanfaat menurunkan kolesterol total. Penelitian ini bertujuan mengetahui pengaruh pemberian serbuk biji labu kuning terhadap penurunan kolesterol total pada tikus Wistar hiperkolesterolemia.

Metode: Penelitian ini merupakan penelitian true experimental dengan pre-post test randomized control group design dengan 24 ekor tikus Wistar yang diinduksi hiperkolesterolemia selama 14 hari, diberi serbuk biji labu kuning dengan dosis P1: 0,54 g/ekor/hari; P2: 0,72 g/ekor/hari; P3: 0,90 g/ekor/hari selama 14 hari. Serum kolesterol total sebelum dan sesudah perlakuan diperiksa menggunakan metode CHOD-PAP. Data dianalisis dengan uji paired t-test dan Anova.

Hasil: Kadar kolesterol total pada kelompok perlakuan 2 (P2) mengalami penurunan dengan nilai p=0,019 dan 3 (P3) dengan nilai $p=0,026$ setelah diberikan serbuk biji labu kuning. Penurunan berturut - turut, pada kelompok $P 2$ dari 71,8 mg/dL menjadi 58,8 mg/dL; kelompok P1 dari 66,5 mg/dL menjadi 54,7mg/dL; dan kelompok P3 dari $61,7 \mathrm{mg} / \mathrm{dL}$ menjadi 53,7 mg/dL. Tidak ada pengaruh dosis serbuk biji labu kuning terhadap penurunan kolesterol total antar kelompok $p=0,534$.

Simpulan: Pemberian serbuk biji labu kuning (Cucurbita moschata) pada kelompok perlakuan 2 (P2) dosis 0,072 g/ekor/hari dan 3 (P3) dosis 0,90 g/ekor/hari selama 14 hari secara signifikan menurunkan kolesterol total pada tikus Wistar hiperkolesterolemia ( $p<0,05)$.
\end{abstract}

Kata kunci : serbuk biji labu kuning; kolesterol total; hiperkolesterolemia

\section{PENDAHULUAN}

Penyakit kardiovaskuler

(CVD)

merupakan penyebab utama tingginya tingkat kematian di seluruh dunia. Data tahun 2007 menyebutkan $33 \%$ penduduk AS meninggal karena CVD dan $48 \%$ secara keseluruhan terjadi di Eropa $^{1}$, sedangkan menurut data Riset Kesehatan Dasar (Riskesdas) 2007, angka kematian akibat penyakit jantung dan pembuluh darah di Indonesia adalah sebesar $59,5 \%{ }^{2}$. Penyakit kardiovaskuler sering terjadi akibat aterosklerosis ${ }^{3}$. Faktor risiko dari penyakit kardiovaskuler (CVD) meliputi hipertensi, kebiasaan merokok, diabetes, gaya hidup, obesitas, peningkatan homosistein, dislipidemia, usia, jenis kelamin dan riwayat keluarga ${ }^{1,4}$.

Dislipidemia merupakan gangguan metabolisme lipid yang menyebabkan kadar lipid darah menjadi tidak normal yang biasanya ditandai dengan meningkatnya kadar kolesterol total, low

\footnotetext{
${ }^{*}$ Penulis Penanggungjawab
} 
density lipoproterin (LDL-C), trigliserid dan menurunnya high density lipoprotein (HDL-C) dalam darah ${ }^{5}$. Peningkatan kolesterol total yang melebihi batas normal merupakan faktor dominan terjadinya dislipidemia ${ }^{6}$. Peningkatan ini disebut hiperkolesterolemia dimana kadar kolesterol total darah $\geq 240 \mathrm{mg} / \mathrm{dL}(\geq 6,2 \mathrm{mmol} / \mathrm{L})^{7}$. Asupan gizi yang tepat serta pola hidup sehat dapat mengontrol kadar kolesterol total dan merupakan faktor penting untuk menjaga kesehatan ${ }^{4,8}$.

Kandungan zat gizi biji labu kuning (Cucurbita moschata) meliputi fitokimia (fitosterol), vitamin (vitamin $\mathrm{C}$, vitamin $\mathrm{E}$ dan beta karoten) dan mineral (magnesium, selenium dan zink) yang dapat menurunkan hiperkolesterolemia 9,10. Selain itu, biji labu kuning juga mengandung serat yang bermanfaat untuk menghambat absorbsi kolesterol di usus sehingga berpotensi menurunkan kadar kolesterol total ${ }^{11}$. Hasil studi 2010 menunjukkan bahwa pada tikus aterogenik yang diberikan diet dengan biji labu kuning selama 8 minggu menujukkan penurunan konsentrasi kadar kolesterol total yang signifikan, yaitu menurun dari 4,89 $\mathrm{mmol} / \mathrm{L}$ menjadi $2,55 \mathrm{mmol} / \mathrm{L}^{12}$.

Penelitian mengenai pemberian serbuk biji labu kuning terhadap kolesterol total belum pernah dilakukan. Berdasarkan uraian tersebut, penelitian ini dilakukan untuk mengetahui bagaimana pengaruh pemberian serbuk biji labu kuning terhadap penurunan kolesterol total pada tikus Wistar hiperkolesterolemia.

\section{METODE PENELITIAN}

Penelitian true experimental dengan prepost test randomized control group design ${ }^{13}$ ini dilakukan di Laboratorium Fisiologi Hewan Fakultas MIPA Universitas Negeri Semarang (UNNES) dengan perlakuan pemberian serbuk biji labu kuning (Cucurbita moschata) pada sampel tikus. Hasil yang dianalisis dalam penelitian ini ialah kadar kolesterol total, berat badan dan asupan.

Sampel tikus yang digunakan yaitu tikus Wistar yang diperoleh dari Laboratorium Fisiologi Hewan Fakultas MIPA Universitas Negeri Semarang. Penentuan jumlah sampel minimal berdasarkan rumus Federer yaitu 6 ekor tikus tiap kelompok. Pada penelitian pemberian serbuk biji labu kuning ini terdiri dari 4 kelompok yang masing-masing kelompok menggunakan 6 ekor tikus sehingga jumlah sampel yang digunakan sebanyak 24 ekor.

Dosis yang digunakan dalam penelitian ini didasarkan pada rekomendasi konsumsi biji labu kuning dari Food and Drug Association (FDA) dalam sehari yaitu $30-40 \mathrm{~g} /$ hari $^{14}$, kemudian dosis tersebut dikonversikan untuk tikus dengan berat badan $200 \mathrm{~g}$ sehingga didapatkan dosis pemberian serbuk biji kuning 0,54 g/ekor/hari; 0,72 g/ekor/hari; dan 0,90 g/ekor/hari. Kelompok dalam penelitian ini yaitu kelompok kontrol (K) mendapat pakan standar dan pakan hiperkolesterol; kelompok perlakuan $1 \quad\left(\mathrm{P}_{1}\right)$ mendapat pakan standar, pakan hiperkolesterol, dan serbuk biji labu kuning 0,54 g/ekor/hari; kelompok perlakuan 2 $\left(\mathrm{P}_{2}\right)$ mendapat pakan standar, pakan hiperkolesterol, dan serbuk biji labu kuning 0,72 g/ekor/hari; dan kelompok perlakuan $3 \quad\left(\mathrm{P}_{3}\right)$ mendapat pakan standar, pakan hiperkolesterol, dan serbuk biji labu kuning 0,90 g/ekor/hari. Seluruh subjek diberikan pakan standar BR-2 Comfeed sebanyak $20 \mathrm{~g} / \mathrm{ekor} / \mathrm{hari}$ serta minum air ad libitum. Selama penelitian dilakukan penimbangan berat badan seminggu sekali dan sisa pakan serta pembersihan kandang dilakukan setiap hari.

Sebelum intervensi, dilakukan perlakuan untuk membuat kondisi hiperkolesterolemia pada hewan coba kelompok kontrol dan kelompok perlakuan dengan pemberian pakan hiperkolesterol dari kuning telur bebek sebanyak $2 \mathrm{ml} / \mathrm{ekor} / \mathrm{hari}$ melalui sonde serta diberikan pakan standar BR-2 Comfeed sebanyak 20 g/ekor/hari selama 2 minggu. Keadaan hiperkolesterolemia pada tikus terjadi jika kadar kolesterol total dalam darah melebihi batas normal $(10-54 \mathrm{mg} / \mathrm{dL})^{15}$.

Pembuatan serbuk biji labu dengan cara biji labu kuning di jemur dibawah sinar matahari selama 3 hari sampai biji labu kuning kering, kemudian diblender dan disaring menjadi serbuk. Setelah itu, ditimbang sesuai dengan perlakuan yang diberikan yaitu $0,54 \mathrm{~g} ; 0,72 \mathrm{~g}$; dan $0,90 \mathrm{~g}$ kemudian ditambahkan air sampai $3 \mathrm{ml}$.

Pengambilan darah dilakukan sebanyak 3 tahap: tahap 1 yaitu setelah 1 minggu pemberian pakan standar (tahap aklimatisasi), tahap 2 yaitu setelah 2 minggu pemberian pakan standar dan pakan hiperkolsterol (tahap hiperkolesterol), tahap 3 yaitu 2 minggu setelah pemberian pakan standar dan serbuk biji labu kuning (tahap aklimatisasi). Sampel darah tikus diambil sebanyak $2 \mathrm{ml}$ melalui pleksus retro orbitalis oleh petugas laboratorium setelah tikus dipuasakan selama 12 jam. Sampel darah tersebut diletakkan pada tabung dan di pisahkan antara darah dan serum melalui proses sentrifuge. Serum darah kemudian digunakan untuk mengukur kadar kolesterol total. Kadar kolesterol total diperiksa menggunakan metode CHOP-PAP Enzymatic Colorimeter Test ${ }^{16}$. 
Data yang diperoleh diolah secara komputerisasi menggunakan SPSS. Perbedaan kadar kolesterol total sebelum dan sesudah perlakuan di uji dengan paired t-test karena data berdistribusi normal. Analisis pengaruh dari kelompok kontrol dan kelompok perlakuan dilakukan dengan uji statistik parametrik Anova ${ }^{17}$.

\section{4 tikus Sprague Dawley jantan (usia 8 minggu)}

Hari ke 1

Pemberian pakan standart BR-

2Comfeed (1 minggu)

Pemeriksaan kadar kolesterol total I

Hari ke 8

Pemberian pakan standart BR-2 Comfeed dan pakan hiperkolesterol (2 minggu)

Hari ke 22

Pemeriksaan kadar kolesterol total II

Hari ke 23

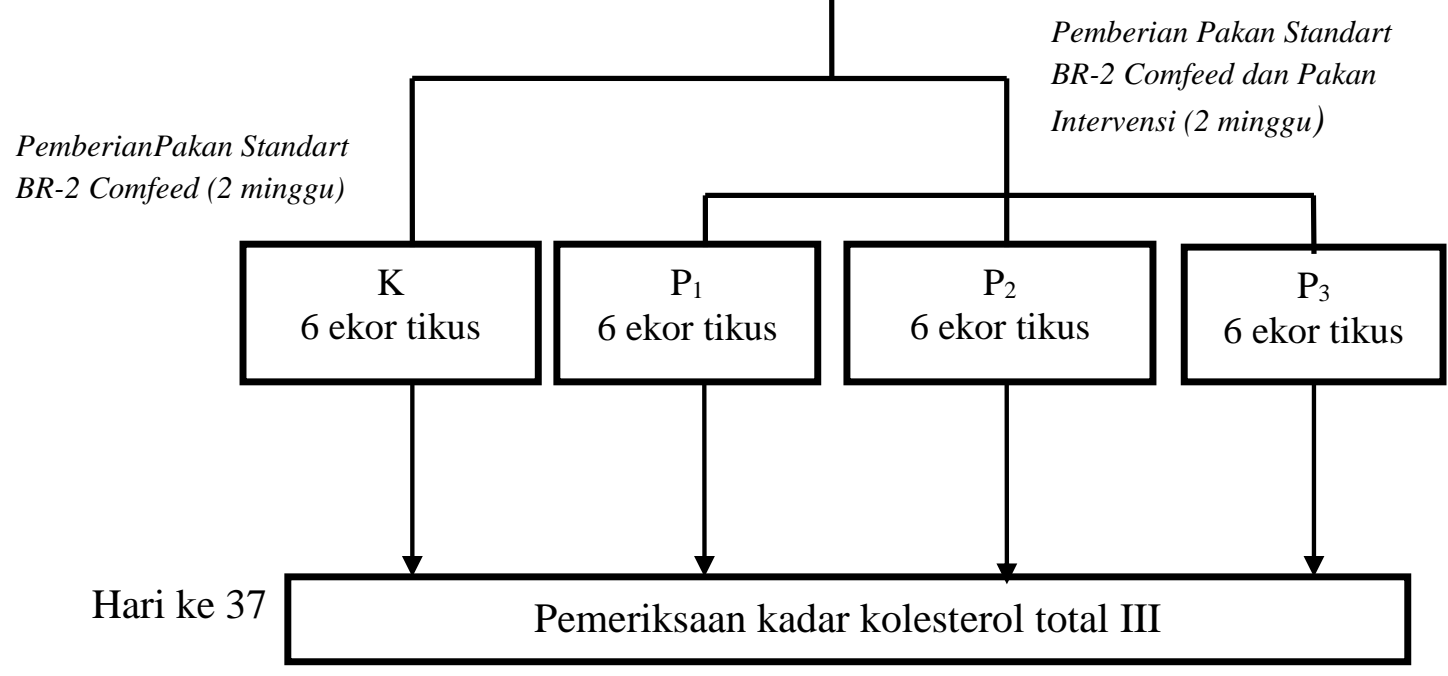

Gambar 1. Bagan Rancangan Penelitian

Keterangan :

$\mathrm{K} \quad=$ Kelompok kontrol (pemberian pakan standar BR-2 Comfeed)

$\mathrm{P}_{1} \quad=$ Kelompok perlakuan 1 (pemberian pakan standar dan serbuk biji labu kuning 0,54 g/ekor/hari)

$\mathrm{P}_{2} \quad=$ Kelompok perlakuan 2 (pemberian pakan standar dan serbuk biji labu kuning 0,72 g/ekor/hari)

$\mathrm{P}_{3} \quad=$ Kelompok perlakuan 3 (pemberian pakan standar dan serbuk biji labu kuning 0,90 g/ekor/hari)

\section{HASIL PENELITIAN}

Semua sampel tikus Wistar jantan dipelihara dalam kandang individu. Tujuannya adalah untuk memudahkan pengontrolan asupan pakan standar selama penelitian. Pemeliharaan dan pembersihan kadang dilakukan setiap hari oleh peneliti. Hal ini dilakukan untuk meminimalisir penyakit dari lingkungan sekitar kandang. Kondisi kesehatan tikus selama penelitian dapat dikatakan sehat meskipun terdapat dua tikus yang drop out karena mati yang kemungkinan dikarenakan kesalahan saat menyonde. Sonde yang seharusnya masuk ke dalam lambung kemungkinan masuk ke dalam paru-paru sehingga tikus mengalami gejala sakit.

\section{Asupan Pakan}

Pakan standar diberikan secara ad libitium, oleh karena itu dilakukan penimbangan sisa pakan setiap hari. Besarnya asupan pakan subjek dapat diketahui dari sisa pakan yang ada, sedangkan pakan hiperkolesterol dan pakan intervensi diberikan melalui sonde, tujuannya agar tikus dapat mengasup semua pakannya. 
Tabel 1. Hasil Analisis Asupan Pakan Standar Tikus

\begin{tabular}{|c|c|c|c|c|c|}
\hline \multirow[t]{2}{*}{ Kelompok } & \multirow[t]{2}{*}{$\mathbf{N}$} & \multicolumn{3}{|c|}{ Asupan Pakan Standar } & \multirow{2}{*}{$\begin{array}{c}P \\
\text { Hiper- } \\
\text { Inter }\end{array}$} \\
\hline & & $\begin{array}{c}\text { Aklimatisasi (g) } \\
\text { Rerata } \pm \text { SD }\end{array}$ & $\begin{array}{c}\text { Hiperkolest } \\
\text { (g) } \\
\text { Rerata } \pm \text { SD }\end{array}$ & $\begin{array}{c}\text { Intervensi } \\
\text { (g) } \\
\text { Rerata } \pm \text { SD }\end{array}$ & \\
\hline $\mathbf{K}$ & 6 & $19,5 \pm 0,53$ & $19,0 \pm 0,70$ & $19,5 \pm 0,41$ & $0,234^{\mathrm{a}}$ \\
\hline P1 (0,54 g) & 6 & $19,0 \pm 0,55$ & $17,9 \pm 1,69$ & $18,7 \pm 1,26$ & $0,206^{\mathrm{a}}$ \\
\hline P2 (0,72 g) & 6 & $19,0 \pm 0,52$ & $17,9 \pm 1,31$ & $18,5 \pm 1,00$ & $0,232^{a}$ \\
\hline P3 $(0,90 \mathrm{~g})$ & 6 & $19,4 \pm 1,15$ & $18,6 \pm 0,94$ & $19,0 \pm 0,98$ & $0,434^{\mathrm{a}}$ \\
\hline
\end{tabular}

Tabel 1 menunjukkan bahwa terjadi penurunan asupan pakan standar tikus selama diberikan pakan hiperkolesterol, namun asupan pakan standar kembali meningkat selama diberikan pakan intervensi.

Hasil analisis dengan uji beda berpasangan, rerata asupan pakan standar kelompok perlakuan hampir sama dengan nilai signifikan $p>0,05$.
Secara keseluruhan, asupan pakan standar dari yang tertinggi sampai terendah yaitu kelompok K, P3, P1, dan P2.

2. Berat Badan

Penimbangan berat badan tikus dilakukan seminggu sekali oleh peneliti. Peningkatan berat badan tikus dapat diketahui dengan menghitung selisih berat badan.

Tabel 2. Hasil Analisis Berat Badan Tikus

\begin{tabular}{|c|c|c|c|c|c|}
\hline \multirow[t]{2}{*}{ Kelompok } & \multirow[t]{2}{*}{$\mathbf{N}$} & \multicolumn{3}{|c|}{$\begin{array}{c}\text { Asupan Pakan Standar } \\
(\text { (g) }\end{array}$} & \multirow{2}{*}{\begin{tabular}{l}
\multicolumn{1}{c}{$P$} \\
Hiper- \\
Inter \\
\end{tabular}} \\
\hline & & $\begin{array}{c}\text { Aklimatisasi } \\
\text { Rerata } \pm \text { SD }\end{array}$ & $\begin{array}{l}\text { Hiperkolest } \\
\text { Rerata } \pm \text { SD }\end{array}$ & $\begin{array}{l}\text { Intervensi } \\
\text { Rerata } \pm \text { SD }\end{array}$ & \\
\hline $\mathbf{K}$ & 6 & $167,5 \pm 5,28$ & $178,0 \pm 7,49$ & $181,8 \pm 14,38$ & $0,668^{\mathrm{a}}$ \\
\hline P1 (0,54 g) & 6 & $164,3 \pm 10,61$ & $175,7 \pm 5,08$ & $178,6 \pm 9,76$ & $0,531^{\mathrm{a}}$ \\
\hline P2 (0,72 g) & 6 & $159,2 \pm 9,26$ & $174,7 \pm 17,03$ & $177,1 \pm 10,17$ & $0,796^{\mathrm{a}}$ \\
\hline P3 (0,90 g) & 6 & $168,0 \pm 16,50$ & $177,4 \pm 8,63$ & $181,1 \pm 9,29$ & $0,559^{\mathrm{a}}$ \\
\hline \multicolumn{5}{|c|}{ Anova $\Delta P$} & 0,998 \\
\hline
\end{tabular}

${ }^{a}$ paire $\overline{t \text {-test } * \text { berbeda bermakna }}$

Tabel 2 menunjukkan bahwa pada semua kelompok terjadi peningkatan berat badan tiap tahap penelitian (tahap aklimatisasi, tahap hiperkolesterolemia, dan tahap intervensi) dengan nilai signifikan $p>0,05$.

Hasil analisis peningkatan $(\Delta)$ berat badan antar kelompok diuji dengan dengan uji Anova menunjukkan tidak ada pengaruh dengan $p>0,05$.
Secara keseluruhan, peningkatan berat badan dari yang tertinggi sampai terendah yaitu, kelompok K, P3, P1, dan P2.

\section{Kolesterol Total}

Pengambilan darah dilakukan pada semua kelompok perlakuan setelah tahap aklimatisasi, tahap hiperkolesterolemia, dan tahap intervensi.

Tabel 3. Hasil Analisis Kolesterol Total Tikus

\begin{tabular}{|c|c|c|c|c|c|c|}
\hline \multirow[t]{2}{*}{ Kelompok } & \multirow[t]{2}{*}{$\mathbf{N}$} & \multicolumn{3}{|c|}{$\begin{array}{l}\text { Kolesterol Total } \\
\text { (mg/dL) }\end{array}$} & \multicolumn{2}{|c|}{ Hiper-Inter } \\
\hline & & $\begin{array}{l}\text { Aklimatisasi } \\
\text { Rerata } \pm \text { SD }\end{array}$ & $\begin{array}{l}\text { Hiperkolest } \\
\text { Rerata } \pm \text { SD }\end{array}$ & $\begin{array}{l}\text { Intervensi } \\
\text { Rerata } \pm \text { SD }\end{array}$ & $P$ & $\Delta(\%)$ \\
\hline $\mathbf{K}$ & 6 & $28,7 \pm 15,44$ & $72,0 \pm 12,00$ & $63,7 \pm 10,71$ & $0,242^{\mathrm{a}}$ & 11,53 \\
\hline P1 (0,54 g) & 6 & $46,3 \pm 13,44$ & $66,5 \pm 20,37$ & $54,7 \pm 10,37$ & $0,130^{\mathrm{a}}$ & 17,74 \\
\hline P2 $(0,72 \mathrm{~g})$ & 6 & $43,8 \pm 8,42$ & $71,8 \pm 13,12$ & $58,8 \pm 7,03$ & $0,019^{a^{*}}$ & 18,11 \\
\hline P3 $(0,90 \mathrm{~g})$ & 6 & $49,5 \pm 4,14$ & $61,7 \pm 7,31$ & $53,7 \pm 7,76$ & $0,026^{a^{*}}$ & 12,91 \\
\hline & \multicolumn{4}{|c|}{ Anova $\Delta P$} & 0,534 & \\
\hline
\end{tabular}

${ }^{a}$ paired t-test $*$ berbeda bermakna 
Kadar kolesterol total tikus normal yaitu $10-54 \mathrm{mg} / \mathrm{dL}^{15}$. Berdasarkan tabel 3 diketahui bahwa setelah tahap aklimatisasi kadar kolesterol tikus dalam keadaan normal, kemudian setelah tahap hiperkolesterolemia dengan pemberian pakan hiperkolesterol terjadi peningkatan rerata kadar kolesterol total pada semua kelompok atau tikus mengalami hiperkolesterolemia.

Pada tahap intervensi dengan pemberian serbuk biji labu kuning, terjadi penurunan rerata kadar kolesterol total pada semua kelompok perlakuan, tetapi masih hiperkolesterolemia kecuali kelompok P3.

Setelah diuji menggunakan paired t-test, diketahui bahwa penurunan kadar kolesterol total P2 dan P3 berbeda bermakna dengan $p<0,05$. Urutan penurunan kolesterol total dari tertinggi ke terendah yaitu P2, P1, P3, dan kelompok K.

Hasil analisis perubahan $(\Delta)$ kadar koleterol total antar kelompok diuji menggunakan uji Anova, diketahui bahwa tidak ada pengaruh pemberian serbuk biji labu kuning terhadap penurunan kolesterol total $p=0,534(p>0,05)$.

\section{PEMBAHASAN}

\section{Asupan Pakan dan Berat Badan}

Pada tahap aklimatisasi, rerata asupan pakan standar dapat dikatakan tinggi, artinya tikus memiliki nafsu makan yang baik. Hasil penelitian menunjukkan perbandingan kelompok-kelompok sebelum dan setelah pemberian pakan hiperkolesterol rata-rata tidak ada beda, tetapi asupan pakan standar pada semua kelompok menurun setelah diberikan pakan hiperkolesterol. Penurunan ini kemungkinan dikarenakan pakan hiperkolesterol dapat memperlambat waktu pengosongan lambung pada tikus sehingga tikus mengasup pakan standar lebih sedikit bila dibandingkan pada tahap aklimatisasi yang hanya diberikan pakan standar saja. Hasil ini sesuai dengan penelitian lain yaitu pemberian diet tinggi lemak memiliki asupan pakan standar lebih sedikit yaitu $80,6 \pm 13,28 \mathrm{kal} / \mathrm{hari}$ dibandingkan dengan saat pemberian pakan standar saja yaitu 90,69 \pm 12,47 kalori/hari ${ }^{18}$.

Rerata asupan pakan standar semua kelompok kembali meningkat pada tahap intervensi. Peningkatan asupan ini kemungkinan dikarenakan pakan intervensi yang diberikan lebih cepat diabsorbsi dibandingkan pakan hiperkolesterol sehingga tikus dapat lebih banyak mengasup pakan standar daripada tahap sebelumnya.

Asupan pakan standar saat aklimatisasi, pemberian pakan hiperkolesterol, dan pakan intervensi dari yang tertinggi sampai terendah yaitu kelompok K, P3, P1, dan P2. Hasil ini sesuai dengan peningkatan berat badannya. Semakin tinggi asupan pakan tikus, semakin tinggi pula peningkatan berat badannya. Selain karena asupan pakan standar, pemberian pakan hiperkolesterol dan pakan intervensi juga dapat menyebabkan peningkatan berat badan dikarenakan tikus mengalami peningkatan asupan energi. Besarnya asupan pakan berpengaruh terhadap besarnya asupan energi yang kemudian disimpan sebagai lemak dan akhirnya berimplikasi terhadap penambahan berat badan dari hewan coba. Peningkatan berat badan pada kelompok dengan diet tinggi lemak akan memiliki sensitifitas kadar leptin yang rendah sehingga nafsu makan dan asupan pakan meningkat, dan berat badan juga mengalami peningkatan ${ }^{18}$.

\section{Kadar Kolesterol Total Sebelum dan Setelah Pemberian Pakan Hiperkolesterol}

Pakan hiperkolesterol yang digunakan untuk menginduksi hiperkolesterolemia pada tikus berupa kuning telur bebek mentah yang diberikan sebanyak 2 g/ekor/hari. Keadaan hiperkolesterolemia pada tikus terjadi apabila kadar kolesterol total $\geq 54 \mathrm{mg} / \mathrm{dL}^{15}$.

Pada tahap aklimatisasi rerata kadar kolesterol tikus dalam keadaan normal, namun ada beberapa tikus yang sudah mengalami hiperkolesterolemia. Hal ini dikarenakan kemungkinan sebelum tikus di aklimatisasi, tikus mengasup pakan standar yang lebih banyak dibandingkan dengan yang lain. Selain itu, penempatan tikus dalam kandang individu kemungkinan dapat menyebabkan stres karena tikus harus beradaptasi dengan lingkungan yang baru. Faktor stres pada hewan coba dapat disebabkan karena tindakan yang dilakukan saat penelitian seperti cara pemegangan, pengambilan darah, pengukuran berat badan, proses penyondean, pengandangan individu, dan pembersihkan kandang ${ }^{19}$.

Hasil analisis data kolesterol total menunjukkan bahwa setelah diberikan pakan hiperkolesterol terjadi peningkatan kolesterol total pada semua kelompok atau hiperkolesterolemia. Peningkatan kolesterol total ini dikarenakan kuning telur bebek yang digunakan sebagai pakan hiperkolesterol mengandung $35 \mathrm{~g}$ lemak dan $884 \mathrm{mg} / 100 \mathrm{~g}$ kolesterol ${ }^{20}$. Kolesterol yang ada di dalam tubuh dapat berasal dari asupan maupun dari 
sintesis kolesterol oleh tubuh itu sendiri, sehingga asupan kolesterol yang tinggi dapat meningkatkan kadar kolesterol total dalam darah ${ }^{21,22}$. Selain itu, asam lemak jenuh dapat meningkatkan kadar kolesterol melalui mekanisme penurunan sintesis dan aktivitas reseptor $\mathrm{LDL}^{22,23}$. Pada sebuah penelitian yang meneliti asupan lemak jenuh dan kolesterol terhadap respon kadar kolesterol, setiap asupan lemak jenuh $1 \%$ dari total energi sehari diprediksi dapat meningkatkan $2,7 \mathrm{mg} / \mathrm{dL}$ kadar plasma kolesterol ${ }^{24}$.

Kadar Kolesterol Total Sebelum dan Setelah Pemberian Serbuk Biji Labu Kuning (Cucurbita moschata)

Pemberian serbuk biji labu kuning dapat menurunkan rasio kolesterol total pada semua kelompok perlakuan (P1, P2 dan P3). Hasil analisis uji beda berpasangan menunjukkan bahwa kolesterol total pada kelompok P2 dan P3 menurun secara signifikan, namun hanya kelompok P3 yang mengalami penurunan hingga batas normal, ini kemungkinan dikarenakan P3 mendapat dosis tertinggi bila dibandingkan dengan kelompok perlakuan lainnya. Penurunan kolesterol total dari tertinggi sampai terendah, yaitu kelompok P2 $(18,11 \%)$, P1 (17,74\%), dan P3 (12,91\%).

Penurunan kadar kolesterol total dipengaruhi adanya kandungan gizi pada biji labu kuning yang bersifat hipokolesterolemia seperti fitokimia (fitosterol), vitamin (vitamin $\mathrm{C}$, vitamin $\mathrm{E}$, dan beta karoten), dan mineral (magnesium, selenium dan zink) serta serat ${ }^{9,10}$. Fitosterol merupakan fitokimia utama yang terdapat pada serbuk biji labu kuning kemungkinan dapat menurunkan kolesterol total. Pada 100 g biji labu kuning kering mengandung $265 \mathrm{mg}$ fitosterol ${ }^{25}$. Fitosterol akan menghambat penyerapan kolesterol dengan cara mengikat misel yang merupakan alat transportasi penyerapan kolesterol dalam usus. Fitosterol akan lebih mudah dihidrolisis dibandingkan dengan kolesterol sehingga mengakibatkan terjadi penurunan penyerapan plasma total kolesterol karena diekskresikan dengan feses ${ }^{26}$. Penurunan konsentrasi kolesterol intrahepatik secara substansial dirangsang oleh HMG CoA reduktase dan aktivitas CYP7 yang mengakibatkan meningkatnya sintesis asam empedu dan kolesterol serta reseptor LDL. Penurunan sisa kilomikron akan menghambat sintesis VLDL akibatnya konversi VLDL ke LDL juga menurun yang diikuti dengan penurunan kolesterol total ${ }^{3}$.

Kandungan vitamin C, vitamin E, dan beta karoten per $100 \mathrm{~g}$ biji labu kuning masing-masing sebesar $1,9 \mathrm{mg}, 35,1 \mathrm{mg}$ dan $9 \mathrm{mcg}^{27}$. Pengaruh vitamin $\mathrm{C}$ dan vitamin $\mathrm{E}$ terhadap penurunan kolesterol total adalah vitamin $\mathrm{C}$ mempunyai efek membantu reaksi hidroksilasi dalam pembentukan asam empedu sehingga meningkatkan ekskresi kolesterol dan menurunkan kadar kolesterol total dalam darah ${ }^{28}$. Vitamin $\mathrm{E}$ menurunkan kadar kolestrol dengan cara menghambat pembentukan skualen 2,3 okside dengan cara bereaksi dengan oksigen membentuk alpha tokoferilkuinon yang bersifat stabil sehingga akhirnya menghambat pembentukan kolesterol ${ }^{29}$. Vitamin $\mathrm{E}$ juga dapat memperlambat progresi aterosklerosis ${ }^{30}$. Beta karoten mampu melindungi membran lipid dari reaksi peroksidasi dan sekaligus menghentikan reaksi rantai dari radikal bebas. Beta karoten dalam penurunan kolesterol yaitu dengan menghambat aktivitas enzim 3-hidroksi-3-metilglutaril CoA yang berperan dalam penghambatan sintesis kolesterol di makrofag ${ }^{29}$.

Kandungan magnesium, selenium dan zink per $100 \mathrm{~g}$ biji labu kuning masing- masing sebesar $592 \mathrm{mg}, 9,4 \mathrm{mcg}$, dan 7,81 $\mathrm{mg}^{27}$. Magnesium menurunkan kadar kolesterol dengan terlibat dalam regulasi enzim kolesterol ester hidrolase ${ }^{29}$. Selenium berikatan dengan protein plasma membentuk kompleks selenoprotein yang merupakan golongan antioksidan. Kompleks ini berfungsi mencegah proses oksidasi kolesterol. Kandungan zink dalam biji labu kuning dapat sebagai antioksidan yang dapat mengubah kolesterol menjadi asam empedu yang melibatkan cholesterol $7 \alpha$ - hydroxylase dan menghambat akumulasi lemak pada tunika intima sehingga pembentukan kolesterol total berkurang ${ }^{31}$.

Serat pada biji labu kuning yaitu sebesar $6,0 \mathrm{~g} / 100 \mathrm{~g}^{27}$. Mekanisme serat dalam menurunkan kadar kolesterol total adalah dengan cara mengikat kolesterol dalam usus halus sebelum kolesterol tersebut diserap kembali di ileum, sehingga pengikatan kolesterol tersebut akan mengakibatkan kolesterol dikeluarkan dalam feses atau memutus siklus perputaran kolesterol ${ }^{29}$.

Penurunan kolesterol total kelompok P2 lebih tinggi $(18,11 \%)$ dibandingkan dengan kelompok P3 (12,91\%) mungkin disebabkan karena asupan pakan kelompok P2 lebih rendah dibandingkan kelompok P3 yang memungkinkan total kalori kelompok P2 juga lebih rendah dibandingkan kelompok P3. Total kalori merupakan jumlah kalori yang diperoleh dari asupan makan selama satu hari pada tikus. Metabolisme tubuh membutuhkan kalori dari makanan untuk diproses, sehingga hasil metabolisme dapat digunakan atau disimpan dalam tubuh. Total kalori yang lebih rendah pada 
kelompok P2 dibandingkan dengan kelompok P3 kemungkinan berdampak pada metabolisme lemak. Rendahnya total kalori yang diasup menyebabkan kadar triasilgliserol yang merupakan hasil metabolisme lemak juga akan rendah. Triasilgliserol bergabung dengan kolesterol di dalam hati dan disintesis menjadi VLDL. VLDL mengalami proses penguraian lipid secara bertahap. Saat lemak disalurkan ke jaringan, VLDL lebih diperkaya kolesterol dan berubah menjadi LDL. LDL merupakan pembawa kolesterol terbesar ${ }^{20}$. Total kalori yang rendah pada kelompok P2 menyebabkan hasil metabolisme lemak juga akan rendah sehingga kadar kolesterol total lebih menurun pada kelompok tersebut dibandingkan pada kelompok P3.

Kelompok $\mathrm{K}$ juga mengalami penurunan kadar kolesterol total $(11,53 \%)$ meskipun tidak diberikan pakan intervensi dikarenakan pada kelompok $\mathrm{K}$ hanya mendapat pakan standar saja dan tidak diberikan pakan hiperkolesterol kembali. Selain itu, pada kelompok $\mathrm{K}$ tidak dilakukan penyondean sehingga dapat mengurangi stres pada tikus yang berpengaruh terhadap kolesterol total.

Penyondean yang terlalu sering dapat meningkatkan stres pada tikus, sehingga tingkat stres yang tinggi meyebabkan kadar kolesterol darahnya lebih tinggi dibandingkan dengan tingkat stres yang terkendali ${ }^{19}$. Stres emosional menyebabkan kadar asam lemak bebas meningkat. Kenaikkan ini akan meningkatkan sekresi VLDL oleh hati yang melibatkan triasilgliserol dan kolesterol ke dalam sirkulasi darah ${ }^{24}$. Penelitian tahun 2004 menunjukkan bahwa dari 9 tikus yang dilakukan penyondean sebanyak $5 \mathrm{ml} /$ hari selama 10 hari, $56 \%$ tikus tersebut mati ${ }^{19}$.

\section{SIMPULAN}

Pemberian serbuk biji labu kuning (Cucurbita moschata) pada kelompok perlakuan 2 (P2) dengan dosis $0,72 \mathrm{~g} / \mathrm{ekor} / \mathrm{hari}$ dan perlakuan 3 (P3) dengan dosis $0,90 \mathrm{~g} / \mathrm{ekor} / \mathrm{hari}$ selama 14 hari secara signifikan menurunkan kolesterol total pada tikus Wistar hiperkolesterolemia $(p<0,05)$.

\section{SARAN}

Pada penelitian selanjutnya perlu dilakukan uji kandungan pada serbuk biji labu kuning (Cucurbita moschata) yang berefek menurunkan

\section{DAFTAR PUSTAKA}

1. Carr TP., Ash MM., Brown AW. Cholesterollowering phytosterols: factors affecting their use and efficacy. Dove Press Journal: Nutrition and Dietary Suplement : 29 July 2010
2. Kementrian Kesehatan Republik Indonesia. Hasil Laporan Riset Kesehatan Dasar - RISKESDAS, 2007

3. Brown AW. Mechanisms of decreased cholesterol absorption mediated by phytosterols in the intestinal lumen. Nutrition \& Health Sciences Dissertations \& Theses by an authorized administrator of DigitalCommons@University of Nebraska - Lincoln; 2011

4. Polychronopoulus E., Panagiotakos DB., Polystipioti A. Diet, lifestyle factors and hypercholesterolemia in elderly men and women from Cyprus. Lipids in Health and Disease 2005, 4:17

5. Lee MH., Kim HC., et al. Prevalence of Dyslipidemia among Korean Adults: Korea National Health and Nutrition Survey 1998-2005. Diabetes Metab J 2012;36:43-55

6. Singhs, Agawal N and Gopal K. Obesity and dislipidemia. Int J Biol Med Res. 2011; 2(3): 824828

7. Roth GA., Fihn SD., Mokdad AH., et al. High total serum cholesterol, medication coverage and therapeutic control: an analysis of national health examination survey data from eight countries. Bull World Health Orga; 2011 ; 89:92-101

8. Izadi, Z., Nasirpour,. et al. MiniReview Reducing blood cholesterol by a healthy diet. International Food Research Journal 19(1): 29-37 (2012)

9. Ardabili AG., Farhosh R., Khodaparast MHH. Chemical Composition and Physicochemical Properties of Pumpkin Seeds (Cucurbita pepo Subsp. pepo Var. Styriaka) Gown in Iran. J. Ag. Sci. Tech. (2011) Vol. 13: 1053-1063

10. Abuelgassim and Al-showayman. The effect of Pumpkin Seeds and L-arginine Supplementation on Serum Lipid Concentration in Atherogenic Rats. Departement of Biochemistry, King Saudi University. Afr J Tradit Complement Alterb Med; 2012

11. Elinge C. M., Muhammad A., et al. Proximate, Mineral and Anti-nutrient Composition of Pumpkin (Cucurbitapepo L) Seeds Extract. International Journal of Plant Research 2012, 2(5):146-150

12. Al-showayman SIA. The effect of pumpkin seed feeding on the serum lipid profile and c-reactive proteinin atherogenic rats. King Saud University Deanship of Gaduate Studies; 2010

13. Sastroasmoro S. dan Ismael S. Dasar-dasar Metodologi Penelitian Klinis. Bagian Ilmu Kesehatan Anak Fakultas Kedokteran Universitas Indonesia, Jakarta. 2008: 109-25

14. Freedy, V., Ronald Ross, Vinood B. 2011. Nuts and Seeds in Health and Diseases Prevention. Academic Press : Amerika

15. Smith, JB., Mangkoewidjojo, S. Pemeliharaan, Pembiakan dan Penggunaan Hewan Percobaan di Daerah Tropis. Jakarta: Universitas Indonesia; $1988: 37-47$ 
16. Arief, M.I., Novriansyah, R., et.al. Potensi Bunga Karamunting (Melastoma malabathricum L.) terhadap Kadar Kolesterol Total Dan Trigliserida Pada Tikus Putih Jantan Hiperlipidemia Yang Diinduksi Propiltiourasil. Progam Studi Kedokteran Fak. Kedokteran, Unlam. 2012

17. Dahlan MS. Statistik untuk kedokteran dan kesehatan. Ed5. Jakarta: Salemba Medica; 2011.hal.69-88

18. Tsalissavrina, Iva. 2006. Pengaruh Pemberian Diet Tinggi Karbohidrat dibandingkan Diet Tinggi Lemak terhadap Kadar Trigliserida dan HDL Darah pada Rattus novergicus Galur Wistar. Jurnal Kedokteran Brawijaya, Vol. XXII, No.2

19. Balcombe, JP., Bernard, ND., et al. Laboratory Rountines Cause Animal Stress. American Association for Laboratory Animal Science;2004: $43 ; 6$

20. Cynthia, Novi. 2013. Pengaruh Pemberian Ekstrak Kacang Hijau (Phaseolus radiatus) terhadap Kadar Kolesterol LDL Serum Tikus Hiperkolesterolemia. Universitas Diponegoro

21. Mayes PA. Lipid dengan makna fisiologis yang penting. Dalam Murray, R.K., Ganner D.K, Rodwell VW. Biokimia Harper 27th edition. Jakarta: EGC ; 2009

22. U.S. Department of Health and Human Services. National Cholesterol Education Progam. NIH Publication No. 05-3290

23. Anwar TM, Linda $\mathrm{E} \mathrm{K}$,et al. Interrelation of saturated fat, trans fat, alcohol intake, and subclinical atherosclerosis. Am J Clin Nutr 2008;87:168-74

24. Mayes, PA. Sintesis, Pengangkutan, dan Ekskresi Kolesterol. Dalam: Murray RK, Ganner DK, Mayes PA, Rodwell VW, editor. Biokimia harper $25^{\text {th }}$ ed. Jakarta: EGC; 2003

25. Lugasi A. Phytosterol-Enriched Foods:Role in Lowering Serum Cholesterol Level, Community Authorising and Conditions of Marketing. National Institute for Food and Nutrition Science, Budapest, Hungary ; 2009 Volume 3, Number 3 . 381-401

26. Gupta AK., Savopoulos CG., et al. Role of phytosterols in lipid-lowering: current perspectives. Q J Med 2011; 104:301-308

27. U.S. Department of Agricultural, Agricultural Research Service. 2010. USDA National Nutrient Database for Standard Reference, Release 23.

28. Dwiputro, BA. Pengaruh Pemberian Jus Lidah Buaya ((Aloe vera) terhadap Kadar Kolesterol Total Serum Tikus Jantan Strain Wistar Hiperlipidemia. Fakultas Kedokteran, Universitas Diponegoro; 2006

29. Harjana, T. Kajian tentang Potensi Bahan - Bahan Alami untuk Menurunkan Kadar kolesterol Darah. Fakultas MIPA, Universitas Negeri Yogyakarta; 2011

30. Syariah, W O, Usmar, et al. Pengaruh Jus Buah Terong Belanda (Cyphomandra betaceae) terhadap
Kadar Kolesterol Total Tikus Putih (Rattus norvegicus) jantan. Fakultas Farmasi, Universitas Hasanuddin. Makassar: 2011; 15:95-98

31. Priyanto, dkk. 2012. Kombinasi Ekstrak Etanol Rimpang Jahe Gajah (Zingiber officinate Roscoe) dan Zn sebagai Antiateroma pada Kelinci New Zealand White Diet Tinggi Kolesterol. Jurnal Bahan Alam Indonesia ISSN 1412-2855 Vol. 8, No. 2 